\title{
設備振動を電力に変換するワイ ドバンド型振動発電技術の開発 \\ DEVELOPMENT OF VIBRATION ENERGY HARVESTER USING BUILDING EQUIPMENT
}

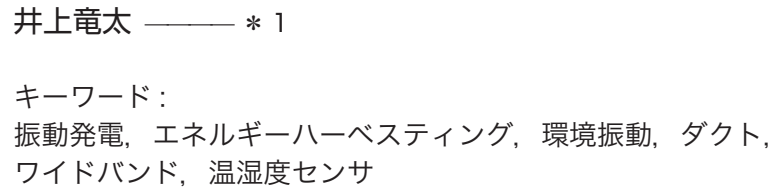

Keywords:

Vibration power generator, Energy harvesting, Environmental vibration, Air-conditioning ducts, Wide frequency range, Temperature and humidity sensor

\section{Ryota INOUE — — $* 1$}

Vibration energy harvesting has been studied as a candidate for powering next generation wireless sensor networks. It is difficult to harness the actual vibration because the amplitude and frequency are not constant. The combination of a vibration generator and an amplification mechanism, achieved increasing the amount of generated power in a wide frequency range. By using the new vibration energy harvester, sufficient energy was harvested from micro-vibration of the airconditioning ducts to supply a temperature and humidity sensor and a RF transmitter.

\section{1.はじめに}

近年、ネットワークに繋がったモノ同士が人を介さずに情報交換 や自動制御を行う Internet of Things (IoT, モノのインターネット) 一の期待が高まっている。一方、期待の高まりに呼応して、これら のモノに取り付けられる膨大な数のセンサへの配線による電源供給 や電池交換が、センサネットワーク社会の実現や普及一の大きな課 題として取り上げられることが多くなってきた。

この問題を解決する技術として注目を集めているのが、今まで注 目されることなく捨てられてきた光, 振動, 熱, 電磁波などの環境 中に希薄に分散しているエネルギーから電力を得る「エネルギー八 一ベスティング」である。得られる発電量は数 $\mu$ W 程度にとどまる が、センサや無線通信機などの小型電子機器の低消費電力化が進ん だことで、この微小な電力でも十分活用できるアプリケーション例 が徐々に登場するようになってきた ${ }^{1) \sim 7) 。 ~}$

本稿は、振動をエネルギー源とする振動発電に関して、空調ダク トや設備機器などの設備振動を電力に変換するワイドバンド振動発 電技術の開発と適用 ${ }^{8},{ }^{9)}$ について報告するものである。以降 2 章で は、振動発電の特徵, 課題について述べる。3 章では、空調ダクト の振動を利用するシステムを取り上げ、ダクトの振動性状や利用す る上での課題について述べるとともに、課題を解決すべく開発した 発電デバイスやセンサモジュールについて紹介する。4 章では、実 稼働オフィスのダクト振動から得た電力でセンサモジュールを駆動 し、温湿度の測定およびデータの無線送信ができることを確認した 環境モニタリング検証試験について述べる。 5 章では、加速度セン サへの電源供給の実現性および設備機器や土木構造物などのインフ ラの健全性モニタリングへの適用の可能性について述べる。

\section{2. 振動発電とは}

振動をエネルギー源とする振動発電は、取り出せるエネルギーが他のエ ネルギー源と比して高いという特徴を持っている。表 1 に示すように、直
射日光を除くと、振動が潜在的に有している抽出可能なエネルギーは他の

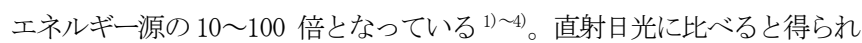
るエネルギーは微小だが、自動車, 鉄道, 機械, 人などが動く度に必ず発 生する振動は、気象や天候に左右されないエネルギ一源であるといえる。

振動発電に関する研究開発は、大学や電子デバイスメーカを中心に行わ

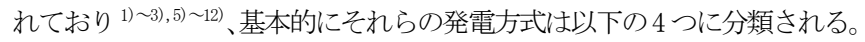
(1)電磁誘導 : 磁石とコイルの相対移動による磁束変化で発電する方式 (2)圧電 : 圧電素子に応力を加えて起電する圧電効果を利用した方式 (3)静電誘導 : 電荷を帯びた基板と、その基盤に対向する基板の相対移 動により発電する方式

(4)磁歪 : 応力を加えることで発生する金属内部の磁場の変化のうち外 部への漏れた分を巻き付けたコイルを通じて電気に変換する方式

いずれの方式においても、一般的な振動発電デバイスは、基本的 に一質点系の振動モデルの構造を有しており、振動源の振動数が質 点系の固有振動数と一致した共振時には大きな発電量が得られる反 面、振動源の振動数が共振から外れた時に発電量が低下寸るという

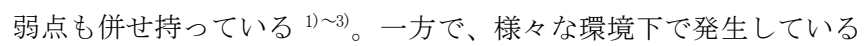
実際の環境振動は、振幅や振動数が一定のものは少なく、ほとんど がランダム性を有している。設置環境ごとに性状が異なる振動源に 対して発電デバイスの発電特性をいかにマッチングさせるかが、振 動発電の実用化への最大の課題といっても過言ではない。

振動発電の代表事例としては、スイッチを押すことで振動を発生 させ、そのエネルギーから得た電力で無線信号を送信する無線スイ

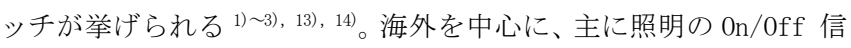

表1 ハーベステイング可能なエネルギー量1) 4)

\begin{tabular}{|c|l|c|}
\hline \multirow{2}{*}{ エネルギー源 } & \multicolumn{1}{|c|}{ 具体例 } & $\begin{array}{c}\text { 単位面積当たりの } \\
\text { エネルギ量 }\end{array}$ \\
\hline 振動 & 人, 機械, 橋梁, 建築物 & $10^{-4} \sim 10^{-3} \quad \mathrm{~W} / \mathrm{cm}^{2}$ \\
\hline \multirow{2}{*}{ 光 } & 直射日光 & $10^{-1} \mathrm{~W} / \mathrm{cm}^{2}$ \\
\cline { 2 - 3 } & 照明, 室内日光 & $10^{-4} \mathrm{~W} / \mathrm{cm}^{2}$ \\
\hline 熱 & 体温, 車の廃熱 & $10^{-5} \mathrm{~W} / \mathrm{cm}^{2}$ \\
\hline 電磁波 & 放送波, 無線LANの電波 & $10^{-6} \mathrm{~W} / \mathrm{cm}^{2}$ \\
\hline
\end{tabular}

本稿は文献 8)，9）を再構成し、加筆・修正したものである。 


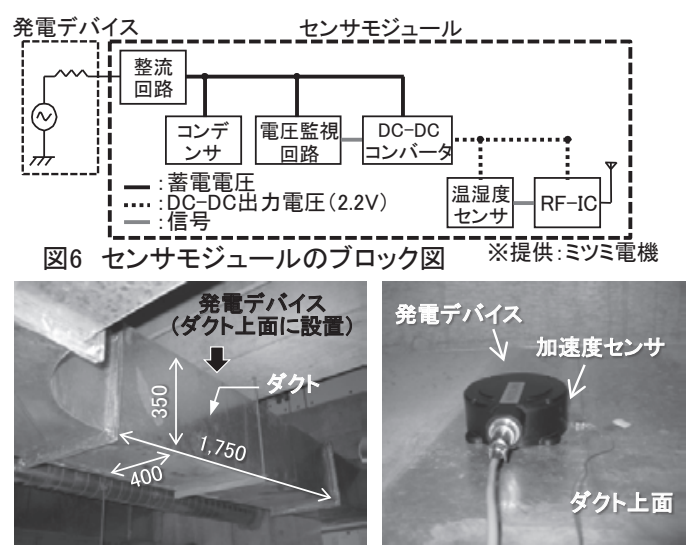

写真2 検証試験の実施状況

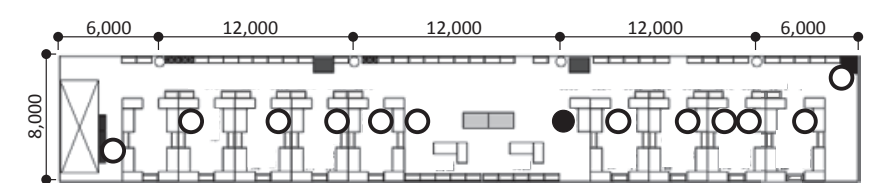

図7 実稼働オフィスの検証試験の結果 O:モジュール駆動OK @: モジュール駆動NG

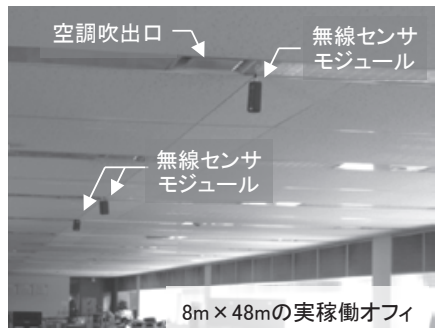

写真3 実稼働オフィスの実証試験＼cjkstart写真4 データ受信機およびモニタリング画面
号や、カードキーの差し込みによるホテル客室扉の開閉信号などへ の適用が報告されている他、国内メーカによるデバイス開発も進め られている。また、人の歩行などの動作で床パネルを加振した際に

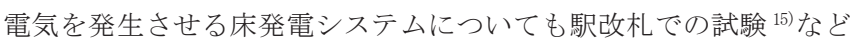
の例が報告されている。しかし、これらの事例のように、発電デバ イスに人力を直接加えることによって強制的に振動を発生させる例 は報告されているものの、上述の共振に係る理由などから、日常的 に発生している環境振動を振動源, エネルギー源として利用した例 は見受けられない。

\section{3. ワイドバンド振動発電技術の開発}

建物内のどこにでも在る環境振動によってセンサの電源が確保で きれば、エネルギー源を人の触る所に限定する必要がなくなり、振 動利用の選択肢や用途をさらに広げることができる。そこで筆者は、 発電デバイス側で発電できる振動数帯域のワイドバンド化により、 微小かつランダムな環境振動による発電の実現を目指すこととした。

\section{1 建物の至る所に存在する振動源 (空調ダクト)の振動特性}

発電デバイスのワイドバンド化の目標を定めるために、建物の至 る所に存在する振動源として空調ダクトを選択し、実稼働中のオフィ ス, 機械室, 倉庫において、ダクト 19 箇所の振動調查を実施した。
図 1 に、調査結果の例として、2 箇所（ダクトA，B）で測定した 加速度波形 (サンプリング振動数: $256 \mathrm{~Hz}$ ) の FFT 周波数分析結果を示 す。図中 $\mathbf{2}$ で示した最大ピークの振動数について比較すると、ダク トA が $20.4 \mathrm{~Hz}$ であるのに対し、ダクト B では $34.3 \mathrm{~Hz}$ となってお り、倍率にして約 1.7 倍の差が生じている。最大ピークの他に、加 速度が $10 \mathrm{mG}_{0-\mathrm{p}}\left(=10 \mathrm{~cm} / \mathrm{s}^{2}{ }_{0-\mathrm{p}}\right)$ を超えるピークを図中 $\nabla$ で示したが、 最大ピークと同様、ダクト $\mathrm{A}, \mathrm{B}$ のピークで同じ振動数のものはな くばらついている。これらの振動数のばらつきは、鋼板の寸法, リ ブ間隔，吊りピッチなどのダクト側の振動特性や、回転数などの送 風機側の特性との共振具合に起因して発生していると考えられる。

図 2 に、全 19 箇所の加速度と振動数の分布図を示寸。全箇所で $10 \mathrm{mG}_{0-\mathrm{P}}$ 以上の加速度が確認されたことから、図には $10 \mathrm{mG}_{0-\mathrm{p}}$ 以上のピークを抜 き出して○で示し、最大ピークのみので示した。プロットは $8 \mathrm{~Hz} \sim 68 \mathrm{~Hz}$ の広帯域に分布しており、最大ピークに限っても $16 \mathrm{~Hz} \sim 38 \mathrm{~Hz}$ （倍率 2.4 倍), $11 \mathrm{mG}_{0-\mathrm{P}} \sim 120 \mathrm{mG}_{0-\mathrm{p}}$ と広帯域に分布している。

この結果から、少なくとも、最大ピークの振動数分布範囲を包含する ワイドバンドな発電特性と、加速度 $10 \mathrm{mG}_{0-\mathrm{P}}$ 程度でもセンサ，無線通信の 電源を供給できる電力が得られる発電能力の両方が、空調ダク卜を振動 源として利用する発電デバイスに求められる性能であることがいえる。

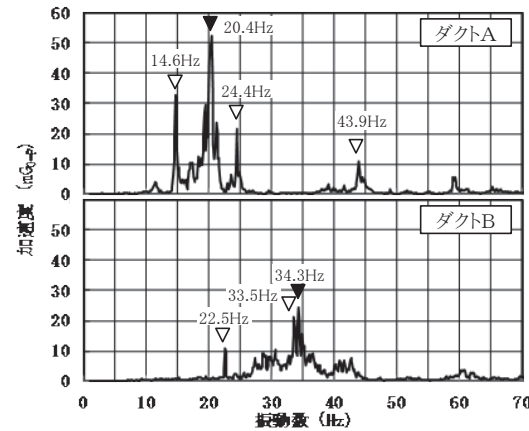

図1空調ダクト振動の周波数分析結果例

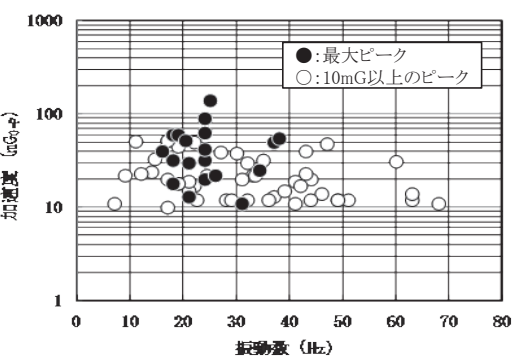

図2 空調ダクトの振動分布

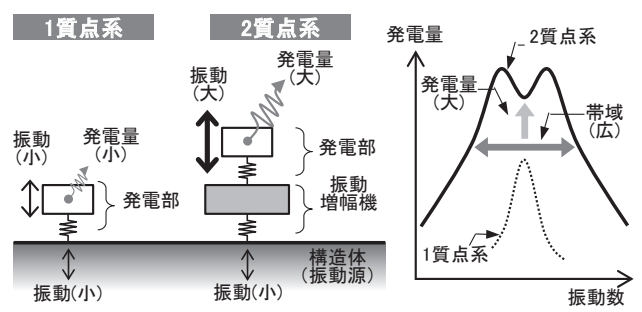

図3 2質点系の構成と効果(概念図)

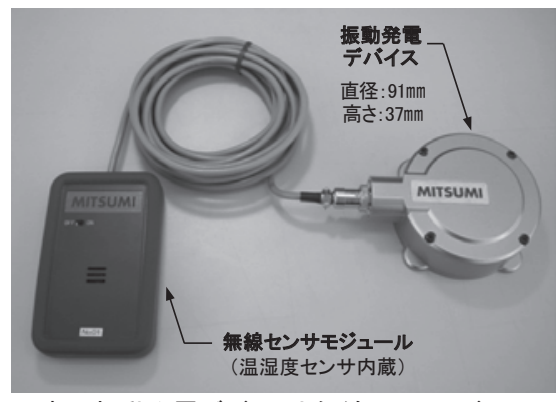

写真1 振動発電デバイスと無線センサモジュール [ 設計·開発協力:ミツミ電機 ]

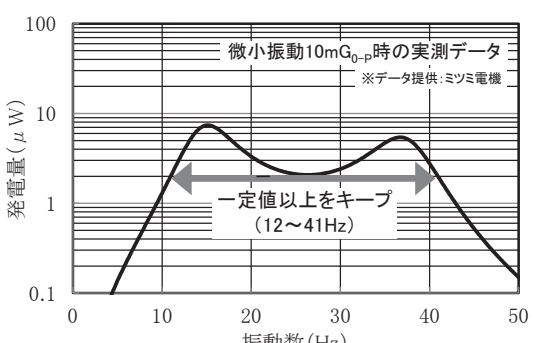

図4 振動発電デバイスの発電特性

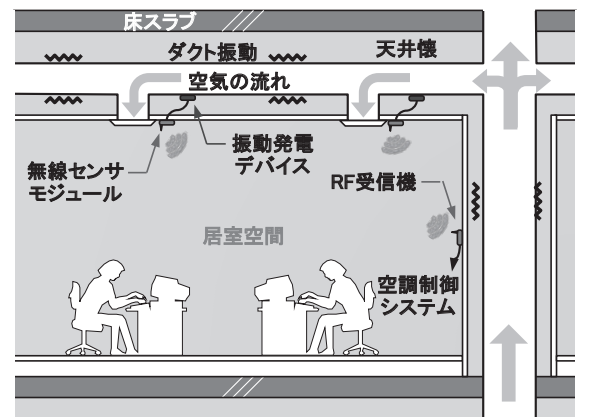

図5 ビル空調設備用の温湿度モニタリングのイメージ 


\section{2 ワイドバンド振動発電デバイス}

空調ダクト用の発電デバイスの発電方式には、電磁誘導を採用した。 一般的な電磁誘導型の発電デバイスは、磁石またはコイルをバネ材で支 持した 1 質点系で構成され、デバイスと振動源の振動数が一致した共振 時に大きな発電量が得られるよう設計される。しかし、不一致時には発 電量が著しく低下寸る弱点を併せ持っている点は先述の通りである。

今回、広帯域に分布するダクト振動に対して発電デバイスのワイド バンド化を図るため 2 質点系の構成を用いた。図 3 に、2 質点系の構 成と効果の概念図を示寸。発電部や振動増幅機の質量や剛性のバラン スによって、発電量の向上や帯域のワイドバンド化が実現可能となっ ている。写真 1 に、開発した振動発電デバイスを示す。発電デバイス は、発電デバイスとして許容される寸法, 重さ, ダクトの振動特性と のマッチングなどを考慮し設計した。

発電デバイスの発電特性を、図 4 に示す。図には、振動台上に発電 デバイスを設置し、スウィープ加振により一定の加速度 $10 \mathrm{mG}_{0-\mathrm{p}}$ を与 えた時の発電量を示した。発電特性は 2 質点系特有の二峰形の形状と なり、 $12 \mathrm{~Hz} \sim 41 \mathrm{~Hz}$ の範囲で極小值 $2 \mu \mathrm{W}$ 以上の発電量が得られるよう になっている。すなわち、本デバイス 1 台で、ダクト振動の最大ピー クの振動数範囲を包含するワイドバンドな発電特性を有している。

\section{3 低消費電力型無線センサモジュール}

発電デバイスのワイドバンド化により、建物の至る所に存在する 空調ダクトの振動を電源として利用できる可能性を広げることがで きた。この電源を利用する用途としては様々なものが考えられるが、 ここでは一例として、図 5 に示すようなオフィス空間における温湿 度などの環境モニタリングを行うセンサモジュールについて述べる

図 6 に、センサモジュールのブロック図を示す。センサモジュール は、整流回路，コンデンサ，電源監視回路，DC-DC コンバータ，温湿 度センサ，無線通信用 IC (図中 “RF-IC” と記す)で構成される。無線 通信の方式は、汎用性や低消費電力性を考慮し ZigBee Green Power の規格に準拠したものとした。発電デバイスによって得られる交流電 力は、まず、整流回路を通じて直流に変換されコンデンサに蓄えられ る。次に、コンデンサの蓄電電圧が $1.4 \mathrm{~V}$ を上回ると DC-DC コンバー タが起動し、電圧 $2.2 \mathrm{~V}$ が温湿度センサと無線通信用 IC に供給され、 温湿度データの取得と送信が実行される。一回のデータの取得と送信 には $450 \mu \mathrm{J}$ の電力量が必要である。データの取得と送信の時間間隔 は、モニタリングする居室の用途などに応じて任意に設定することが できる。設定した時間の間に $450 \mu \mathrm{J}$ 以上の電力量が供給されれば、 空調稼働時にはセンサモジュールは停止することなく稼働し、データ を送り続けることができる。上述の発電デバイスを $10 \mathrm{mG}_{0 \mathrm{p}}$ 程度の振 動環境下に 5 分間設置して得られる発電量は $600 \mu \mathrm{J}(=2 \mu \mathrm{W} \times 300$ 秒 $)$ 以上であり、急激な温湿度変化が生じないオフィス空間において十分

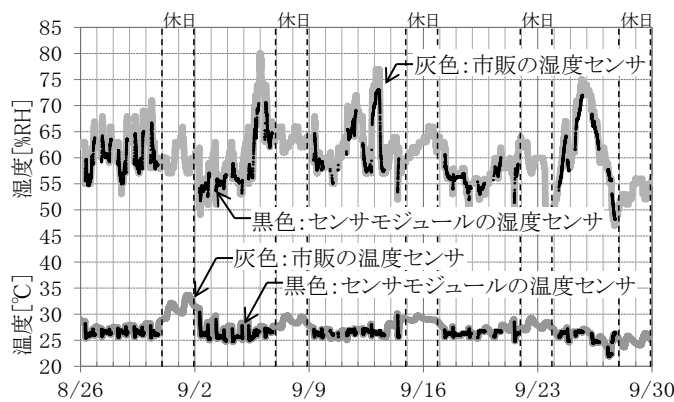

図8 温湿度の長期モニタリングのデータ例 (5週間分)
ともいえる 5 分間隔でのモニタリングが行える仕様となっている。

空調停止によって振動エネルギーの供給が途絶えた場合は、コンデンサ の蓄電電力によって最長で約 100 分 $(=5$ 分/回 $\times 20$ 回 $)$ の測定が可能で、蓄 電電圧が $0.9 \mathrm{~V}$ を下回った時点で停止する仕様となっている。空調稼働時の 環境モニタリング用途であれば、本センサモジュールは十分に役割を果た すことができる。空調停止時にもデータ収集が必要な用途では、停止中も センサモジュールが駆動し続ける容量を持ったコンデンサが必要となる。

\section{4. 空調ダクトの振動利用による温湿度モニタリング検証試験}

空調ダクトの振動により電源を供給されたセンサモジュールによ って温湿度モニタリングができることを検証するため、平面寸法 $8 \mathrm{~m}$ $\times 48 \mathrm{~m}$ の実稼働オフィスにおいて試験を行った。検証試験の実施状 況として、写真 2 に天井懐側のダクトおよび発電デバイスの設置状 況を、写真 3 にオフィス空間側の様子を示す。

\section{1 センサモジュール駆動，通信の確認}

検証試験の結果、ダク卜振動からの電源供給によりセンサモジュー ルの駆動が確認できた箇所を、図 7 に示す。無作為に選んだ天井懐内 のダクトのほぼ全数にあたる $92 \%$ (12/13 箇所)において空調吹出口の 温湿度データを測定できることが確認，検証できた。オフィス両端の 空調機から離れるほどダクト振動は小さくなる傾向があり、中央付近 の 1 箇所だけはセンサモジュールの駆動を確認できなかった。

写真 4 に、データ受信機およびモニタリング画面を示す。センサ モジュールから送信された温湿度データは、受信機 (USB ドングル) にて受信され、PC に保存される。保存データは参照でき、モニタリ ングソフトを用いて現在の温湿度や履歴を確認することができる。現 時点のシステムでも、センサモジュール 12 台のデータを保存, 表示 することが可能で、将来的にはさらに対応台数を増やす予定である。

振動発電による電源供給と並んで、無線によってデータを送受信 できる通信距離やその信頼性の確認は、検証すべき重要な項目であ る。今回、敢えて厳しい通信条件として、軽鉄下地で吊り下げられ た天井懷内のボード上側にセンサモジュールを移設した場合につい て、通信テストを実施している。その結果、天井懐のセンサモジュ ールから送信されたデータを、約 $30 \mathrm{~m}$ 離れたオフィス空間内におい て 100\%の受信率で受信できることが確認できた。意匠的に送信アンテ ナを室内側に設けることができない場合でも、同一室内であれば、天 井懐内と居室の間で十分にデータ送受信ができることが確認できた。

\section{2 温湿度の長期モニタリング試験}

検証試験後、センサモジュールと同じ位置に電池駆動の市販の温湿 度センサを設置し、同一建物内において温湿度の長期モニタリング試 験を実施した。2013 年 1 月の設置から 2 年を経た現在でもシステムは 正常に駆動している。 5 週間分 (2013 年 8 月 26 日〜9 月 30 日)の結果 を示した図 8 より、空調稼働時(夜間，休日以外) は、市販センサとほ ぼ同じ温湿度をセンサモジュールで測定できること、すなわち、電池 交換や電源配線なしに温湿度モニタリングができていることがわか る。今後、センサ数を増やしきめ細かく温湿度分布を把握することで、 居室の快適性向上や空調の効率運転に繋げていきたいと考える。

\section{5. 温湿度モニタリング以外の用途への適用検討 \\ 5. 1 加速度センサへの電源供給}

本技術が電源を供給できるセンサは、温湿度センサに限らない。 
図 9 に、各種センサの消費電流の目安 ${ }^{6}$ を示す。いずれのセンサも、 温度センサより消費電流が大きいが、センシング頻度や駆動時間が 少ない用途であれば振動発電でも十分に駆動できる可能性がある。

ここでは、様々なセンサの中から、特に、インフラの健全性モニ タリングなどへの活用が期待されている加速度センサを取り上げ試 算することとする。図 9 を参考に、仮に消費する電流を $200 \mu \mathrm{A}$, 電 圧を $2 \mathrm{~V}$ とすると、 1 分間の駆動に必要な電力量は $24,000 \mu \mathrm{J}$ となる。 発電デバイスを $10 \mathrm{mG}_{0}$-P の振動環境下 (発電量 $2 \mu \mathrm{W}$ ) に設置した場合 にはこの電力量を 200 分で供給できる計算となる。

\section{5．２インフラの健全性モニタリングへの適用の可能性}

加速度センサのインフラへの適用用途としては、まず、回転機器 の状態監視が挙げられる。1 日に 1 回程度の頻度で、1 分間の加速度 波形が計測できれば、経年劣化による軸ブレなどの検知が可能であ り、振動発電での電源供給が十分可能な頻度, 駆動時間となってい る。本技術を適用することで、従来は人が巡回し判断していた機器 の維持管理の省力化を図ることができる上、発電の履歴などから機 器の実稼働時間の記録を参照することで、適切な時期に部品交換や 機器更新を行えるようにもなる。

回転機器の状態監視の用途では、エネルギー源としてダクト振動で はなく監視対象の機器振動から電力を得た方が効率的である。そこで、 写真 5 に示寸 4 種の設備機器について振動測定を実施した。測定デー タの $1 / 3$ オクターブ周波数分析結果を、図 10 に示す。ピーク振動数 は異なるものの、いずれの設備機器でも $10 \mathrm{mG} 0$-P の以上の振動が発生 していることがわかる。この結果と、本振動発電デバイスの発電特性 および 5.1 にて述べた電力量から、機器の振動から加速度センサの電 源を供給し、状態監視を行える可能性は十分にあると考えられる。

加速度センサは、機器以外にも、橋梁, トンネルなどの土木構造物の モニタリングへの活用も期待されている。これらのモニタリングには、 (1)構造物のデータを正確に把握するセンシング, (2) センシングしたデ 一タから構造物の状態を判定する解析技術，（3）取得したデータを正確 にサーバに送る無線通信, (4) センサや無線を駆動するための自立電源、

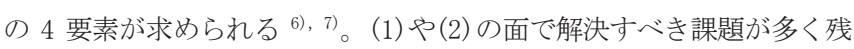
されている現状ではあるものの、本稿で紹介した振動発電は(3) と (4) において一定の役割を果たせる技術であり、今後、土木構造物の健全性 モニタリングなどへの適用も図りたい。

\section{6. おわりに}

本稿では、ワイドバンド振動発電デバイスと低消費電力型センサモジュ ールを開発し、空調ダクトの振動を温湿度センサの電源として利用した環 境モニタリング検証試験について述べた。また、加速度センサへの電源供

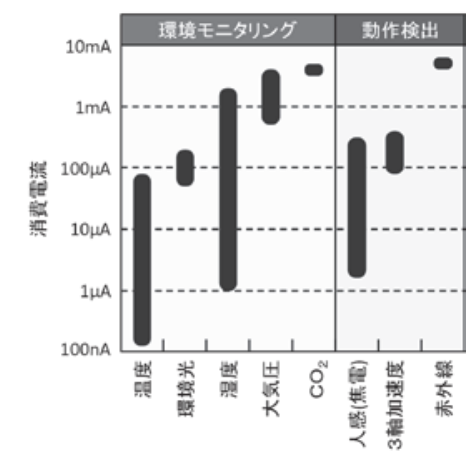

図9 各種センサの消費電流の目安

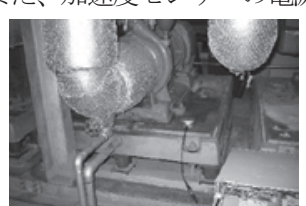

(A)熱源ポンプ

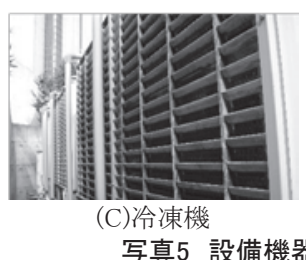

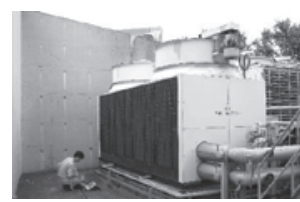

(B)冷却塔

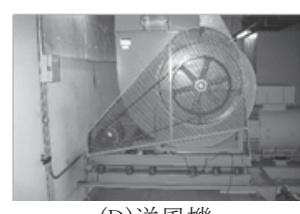

(D)送風機

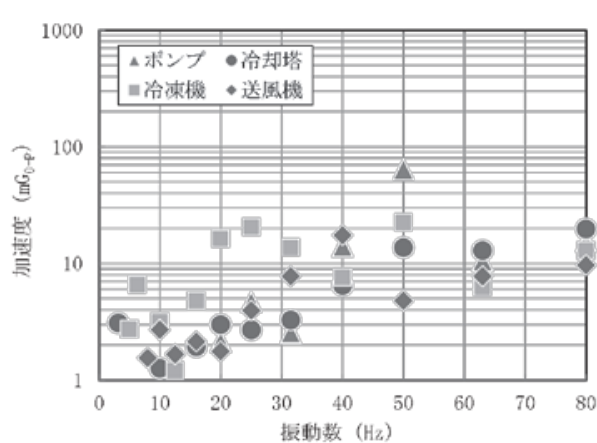

図10 設備機器の振動分布
[2015 年 2 月 18 日原稿受理 2015 年 4 月 1 日採用決定］ 